IZA DP No. 4264

Will You Still Need Me - When I'm 64?

Jan C. van Ours

June 2009 


\title{
Will You Still Need Me - When I'm 64?
}

\author{
Jan C. van Ours \\ CentER, Tilburg University, \\ University of Melbourne, CEPR and IZA
}

Discussion Paper No. 4264

June 2009

\author{
IZA \\ P.O. Box 7240 \\ 53072 Bonn \\ Germany \\ Phone: +49-228-3894-0 \\ Fax: +49-228-3894-180 \\ E-mail: iza@iza.org
}

Any opinions expressed here are those of the author(s) and not those of IZA. Research published in this series may include views on policy, but the institute itself takes no institutional policy positions.

The Institute for the Study of Labor (IZA) in Bonn is a local and virtual international research center and a place of communication between science, politics and business. IZA is an independent nonprofit organization supported by Deutsche Post Foundation. The center is associated with the University of Bonn and offers a stimulating research environment through its international network, workshops and conferences, data service, project support, research visits and doctoral program. IZA engages in (i) original and internationally competitive research in all fields of labor economics, (ii) development of policy concepts, and (iii) dissemination of research results and concepts to the interested public.

IZA Discussion Papers often represent preliminary work and are circulated to encourage discussion. Citation of such a paper should account for its provisional character. A revised version may be available directly from the author. 


\section{ABSTRACT}

\section{Will You Still Need Me - When I'm 64?*}

For various reasons the relationship between age and productivity is a matter of policy concern. I present new empirical research showing how productivity is affected by age. I study age effects at the individual level by analyzing data on running and publishing in economic journals. Furthermore I present empirical evidence at the firm level on the relationship between age, wage and productivity. In particular I address the potential wageproductivity gap that might occur at higher ages. I conclude that the productivity of older workers indeed decreases with their age. Nevertheless, the decline is limited. Furthermore, I find no evidence of a pay-productivity at higher ages.

JEL Classification: J14, J24, J31

Keywords: age, productivity, matched worker-firm data

Corresponding author:

Jan C. van Ours

CentER

Tilburg University

P.O. Box 90153

5000 LE Tilburg

The Netherlands

E-mail: vanours@uvt.nl

\footnotetext{
* The title is based on "When I'm sixty-four", a song from the Beatles album "Sgt. Pepper's Lonely Hearts Club Band" (1967). The paper is an extensive version of my Presidential Address at the European Society for Population Economics annual conference in Seville, June 12, 2009.

Excellent research assistance of Willemijn van den Berg and Lenny Stoeldraijer is gratefully acknowledged. The analysis of the age-wage-productivity relationship using matched worker-firm data is part of research sponsored by the Netherlands Ministry of Social Affairs and Employment. I thank the Ministry for their generous financial support. The matched worker-firm data were made available through Statistics Netherlands. I thank Paul van Seters for making his personal running data available for analysis. I also thank participants of the ESPE conference and Guyonne Kalb, Peter Kooreman and Daniel van Vuuren for their comments.
} 


\section{Introduction}

Over the next decades, European countries will experience a steep increase in the share of elderly persons in the population and a large decline in the share of the population of prime working-age. The number of workers retiring each year will increase and eventually exceed the number of new labor market entrants. The ratio of older inactive persons per worker could rise to almost one older inactive person for every worker in 2050 (OECD 2006). Population aging occurs because birth rates are low and people live longer. Since 1960 life expectancy at age 65 increased from 13 to 17 years for men and from 15 to 20 years for women. However, not only the labor force is aging, also the length of working lives has been declining because workers retired earlier than they used to. To the extent that this was induced by government policy this is surprising - to say the least - as the aging of the population was foreseen for decades.

With an aging labor force the labor market position of older workers is a matter of policy concern. Currently, in many countries older workers are not very likely to loose their job but once they have lost their job they need a long time to find a new one. This situation is often attributed to the gap between wage and productivity, i.e. older workers having a wage that is higher than their productivity. At their current employer older workers are protected by employment protection legislation including seniority rules. But once older workers become unemployed, employers are reluctant to hire them.

Surprisingly little is known about the relationship between age and productivity. Most employers - and probably most employees - seem to believe in a rule of thumb that average labor productivity declines after some age between 40 and 50. This assumption is so common that few attempts have been made to gather supporting evidence: "why bother to prove the obvious?" (Johnson, 1993). There is a lot of speculation but limited empirical evidence. Therefore, in this paper I present some new empirical evidence on the relationship between age and productivity, measured in various dimensions. I use examples at the individual level by analyzing data on running and publications in economic journals. Furthermore I present empirical evidence at the firm level adding to that the relationship between wage and productivity. After all, from an economic point of view it is not so much the age-productivity relationship but the potential pay-productivity gap at higher ages that is worrying. To the extent that running performance represents physical productivity I find evidence of a productivity decline after age 40. However, to the extent that publishing in economics journals represents mental productivity I find no evidence of 
a productivity decline even after age 50. Finally, when measured at the firm level I find no evidence of an increasing pay-productivity gap at higher ages.

The set-up of the paper is as follows. Section 2 discusses the relationship between age and productivity and potential explanations of the wage-productivity gap for older workers. In section 3 I present empirical evidence on the age-productivity relationship at the individual level, analyzing data on running and publishing in economics journals. Section 4 presents empirical findings concerning the wage-productivity age profile using matched worker-firm data from Dutch manufacturing. Section 5 concludes.

\section{Population aging and productivity effects}

\subsection{General notions}

It is not easy to establish the relationship between age and productivity for a variety of reasons: productivity is a complex phenomenon, the age-productivity profile changes over time, is potentially endogenous and individual profiles are not easily aggregated (Garibaldi et al., 2010).

Productivity is multidimensional with the effects of aging depending on the extent to which age-induced changes in work experience, physical strength and cognitive abilities are relevant for work performance. Accumulated experience benefits employees performance throughout the working life. However, physical strength and health are reduced as workers grow older. Concerning cognitive abilities the age effect is not uniform (Skirbekk, 2003). Some cognitive abilities such as vocabulary size and verbal ability increase to a relatively late age or remain stable throughout the working life. Other cognitive abilities such as speed and memory deteriorate with age. Different types of work require different cognitive abilities and physical strength. The net effect of the age-specific productivity determinants depend on how individual skills are used in the work process, how the work is organized and how the individual interacts with other workers and firm level factors such as technology. The variation in the type of skill required in the workplace is likely to cause differences in the age-productivity pattern across occupations.

A further complication in assessing the importance of the age effect on productivity are calendar time changes in the age-productivity profile. This is due to changes in the demand for skills as well as changes in individual characteristics across generations. New technologies and new working techniques imply a decreased need for manual labor and an 
increase in the demand for high skilled workers. Physical strength and bodily co-ordination have become less important in the workplace, while cognitive abilities are increasingly important. Over time, health levels have improved at adult and older ages. Improved agespecific mental and physical health levels are likely to create a strong positive effect on the work potential of older workers. All in all, even if it would be possible to establish the current relationship between age and productivity, drawing conclusions about the future age-productivity profile is not straightforward.

Another complication is that the age-productivity profile is not exogenous to labor market institutions. If a worker anticipates early retirement he will be less eager to invest in training to prevent his productivity from deteriorating. If an employer expects his worker to retire early he too will not have an incentive to invest in maintaining productivity. One of the main problems from a policy point of view is that population aging requires changes in labor market institutions and social norms that are opposite to the changes that have been implemented in the recent past when labor market institutions were adjusted to facilitate early departure from the labor force.

Finally, there is the issue of aggregation. Aging has an unambiguous effect on the age structure of the population: the number of old-age individuals increases relative to young and prime age individuals. Aging will affect the size and composition of the workforce but as yet the consequences at aggregate level are unclear. If workers of different ages are imperfect substitutes in production aging will affect relative wages of younger and older workers. When young workers become scarcer the relative wage of young workers should rise. Whether they actually do also depends on the labor market institutions. Therefore, it is difficult to draw straightforward conclusions except for the obvious conclusion that even if at the individual level productivity would decline with age there may be compensating effects at the aggregate level.

\subsection{Pay-productivity gap}

There are several explanations for an age related pay-productivity gap (see for an overview Van Vuuren and De Hek, 2009). According to Lazear (1979) age-earnings profiles are upward sloping because this will discourage workers from shirking. Workers and firms engage in long-term relationships in which the worker is initially underpaid - the wage is lower than the value of the marginal product - while later on in life the worker is overpaid. Such delayed-compensation contracts will discourage the worker from shirking, 
but at the same time require mandatory retirement to avoid firms paying more than the value of the marginal product. Lazear's theory requires that workers and firms want to be engaged in long-term relationships and assumes that rising earnings do not reflect increased productivity. A complicating factor is that the current relationship between productivity and age is at least partly determined by selective attrition from employment. The least productive workers are most likely to be the first to retire. If not accounted for, this selection effect will lead to a downward bias in the estimated productivity decline attributing to aging.

The age related pay-productivity gap is also attributed to union bargaining (Weiss, 1985). If unions care more for senior workers and their preferences wages increase according to seniority. Incumbent workers controlling the union exploit newcomers. Furthermore, employment protection legislation in particular the last-in first-out rule may protect older workers more than younger workers. Due to this rule firms cannot simply replace high wage more senior workers for low wage young workers. Finally, the age related pay-productivity gap may be due to workers preferring increasing wage profiles over flat or decreasing wage profiles of greater monetary value (Loewenstein and Sicherman, 1991).

\section{Individual productivity - body \& mind}

\subsection{Body: run for fun}

The physical component of individual productivity is sometimes investigated through sports achievements. Fair (1994) studies U.S. data on men's running records finding that the age related physical deterioration is rather low. For example between age 35 and 55 the time needed to run the half marathon increases annually with $0.8 \%$, while between 55 and 65 the annual increase is $1.1 \%$. This means for example that a runner aged 65 only needs $30 \%$ more time to run the half marathon than a runner aged 35 . In the age range 40 to 70 annual deterioration rates for sprint - 100, 200 and 400 meter track - are $0.6 \%$, for longer distances $0.8 \%$, for men 100 meter swimming $0.5 \%$. Although at higher ages the deterioration rates increase, for a fairly wide age range productivity losses are quite small. Sterken (2003) uses U.S. age-dependent road-racing records to analyze the relationship between age and running speed on various distances. He finds that even at a high age it is still possible to run fast, with a drop in speed which in line with medical studies on the impact of aging on maximal oxygen uptake. 
Tab. 1: Data on $10 \mathrm{~km}$ run

\begin{tabular}{ccc|lcccc}
\hline & & & \multicolumn{2}{|c}{ Number } & \multicolumn{2}{c}{ Observations } & \multicolumn{2}{c}{ Individuals } \\
Year & Women & Men & of times & Women & Men & Women & Men \\
\hline 1998 & 9 & 56 & 2 & 114 & 404 & 57 & 202 \\
1999 & 20 & 121 & 3 & 63 & 258 & 21 & 86 \\
2000 & 38 & 178 & 4 & 24 & 216 & 6 & 54 \\
2001 & 42 & 170 & 5 & 40 & 165 & 8 & 33 \\
2003 & 20 & 127 & 6 & 12 & 132 & 2 & 22 \\
2004 & 42 & 155 & 7 & 7 & 70 & 1 & 10 \\
2005 & 34 & 157 & 8 & 0 & 32 & 0 & 4 \\
2006 & 27 & 150 & 9 & 9 & 0 & 1 & 0 \\
2007 & 16 & 97 & & & & & \\
2008 & 21 & 66 & & & & & \\
\hline Total & 269 & 1277 & \multicolumn{7}{|c}{269} \\
\hline
\end{tabular}

\subsubsection{0 kilometers}

In my analysis I use data from the "Wolfskamerloop", a $10 \mathrm{~km}$ run which since 1999 is organized once a year in the Fall in Huizen, a small provincial town in the Netherlands. ${ }^{1}$ Although it has participants from all over the Netherlands the majority of the runners doesn't live far from the track. The participating runners are amateurs who run for fun. They may invest time in training but the amount will usually be limited. Of course there is individual-specific variation in speed over time because the training investment may vary over time but there shouldn't be a systematic relationship between age and training intensity. Also there may be variation in speed because the weather conditions may differ (temperature, sun, wind, rain) but again there should not be a systematic change over the years. Training intensity may vary across individuals because some individuals are more ambitious or have more ability. To allow individual effects to be taken into account in the analysis, the dataset includes individuals which participated at least twice in the period for which data are available, the years 1998 to 2008. Table 1 shows that there is information of 96 women and 411 men who generated 269 and 1277 observations. Most individuals only participated twice but there are also 4 runners that participated in 8 runs.

The upper part of Figure 1 gives an overview of the observations. As shown there is a tendency of the speed to go down with age but at any given age there is a huge variation

\footnotetext{
${ }^{1}$ The run is largely shielded from the wind because most of the track is in a forest. Nevertheless, in the year 2002 the run was canceled because of a heavy storm that might have endangered the runners. Between 1983 and 1998 the Wolfskamerloop was organized 3 to 4 times a year over a different track.
} 
Fig. 1: Running 10km - 1998-2008

a. All data

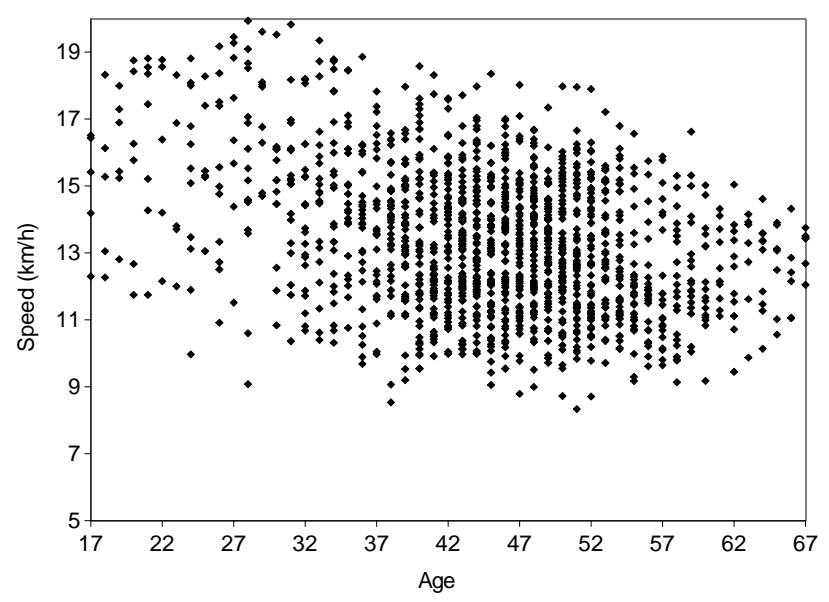

b. Average speed per year

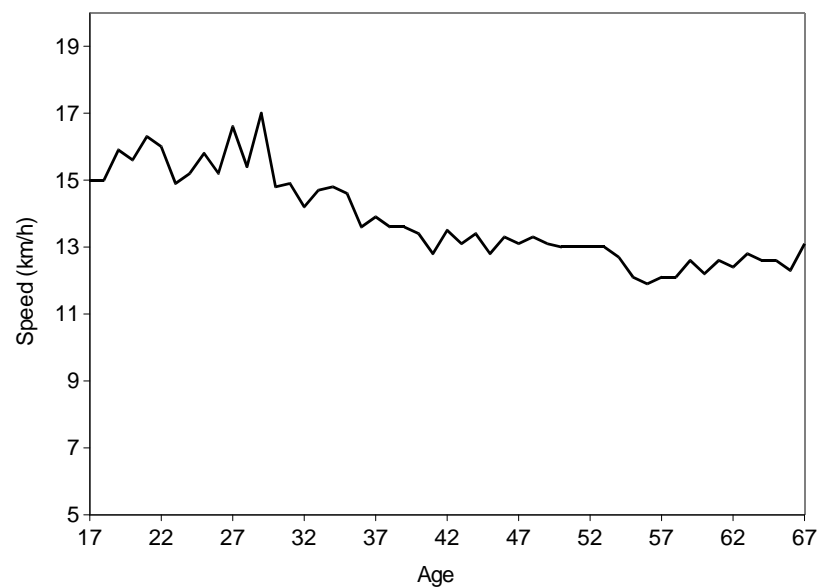


in average speed. The lower part of Figure 1 presents the average speed by age group. As shown the average speed goes down from more than 15 kilometers per hour $(\mathrm{km} / \mathrm{h})$ for individuals younger than 25 to about $13 \mathrm{~km} / \mathrm{h}$ for individuals age 40 . After that the average speed hardly drops.

The baseline estimation exploits the panel character of the data relating the logarithm of average speed to age:

$$
\log \left(s_{i t}\right)=\alpha_{i}+\beta a_{i t}+\epsilon_{i t}
$$

where $s$ is the average speed, $a$ is the age at the time of the run, $i$ represents individual, $t$ represents time, the $\alpha_{i}$ are individual fixed effects, $\beta$ is the parameter of interest and $\epsilon$ represents the error term. Note that this specification takes individual differences in ability or time invariant differences in training intensity into account. Note also that calendar year fixed effects cannot be introduced because these would correlate perfectly with age. Hence, the identifying assumption to establish the effect of age on speed is that there is no systematic change in the conditions of the run over time. ${ }^{2}$

Table 2 shows the parameter estimates. The first column gives the average speed which is higher for men $(13.6 \mathrm{~km} / \mathrm{h})$ than for women $(12.1 \mathrm{~km} / \mathrm{h})$. The average drop in running speed is $0.6 \%$ per year for men and $0.4 \%$ per year for women. The table also makes a distinction between men and women of different birth cohorts. As shown the average speed goes up with the birth cohort. Men born in the 1940s on average had a speed of $12.8 \mathrm{~km} / \mathrm{h}$, for women of the same birth cohort this was $11.1 \mathrm{~km} / \mathrm{h}$. Men born from 1970 onwards had an average speed of $15.5 \mathrm{~km} / \mathrm{h}$, while for women this was 12.8 $\mathrm{km} / \mathrm{h}$. Also the decline of the average speed with age differs between birth cohorts. Men born in the 1940s have an average decline of $1.2 \%$ per year while for women this is $1.4 \%$. For men born in the 1950s and 1960s there is a decline of $0.5 \%$ per year. Men born from 1970 onwards face no decline in their running speed and neither do women of this birth cohort. So, the age effect starts to become important from about age 40 onwards and is increasing as individuals grow older.

One of the issues when establishing the relationship between age and productivity is endogenous attrition. This also applies to running. As shown in Table 2, the variation in running speed is declining with age, which could suggest that a selective group remains

\footnotetext{
${ }^{2}$ By way of sensitivity analysis, to take variation in circumstances across the years into account, I included the speed of the numbers 1 for every race as a regressor. This did not affect the relevant parameter estimates.
} 
Tab. 2: Parameter estimates individual productivity - run for fun

\begin{tabular}{lccccc}
\hline a. Running $10 \mathrm{~km} ; 1998-2008$ & & & \\
\hline Birth year & $\begin{array}{c}\text { Average speed } \\
(\mathrm{km} / \mathrm{h})\end{array}$ & C.V. & $\begin{array}{c}\text { Change } \\
(\% / \text { year })\end{array}$ & $\begin{array}{c}\text { Number of } \\
\text { observations }\end{array}$ & $\begin{array}{c}\text { Number of } \\
\text { individuals }\end{array}$ \\
\hline Men & & & & & \\
$<1950$ & 12.8 & 0.14 & $-1.2(8.3)^{* *}$ & 217 & 74 \\
$1950-59$ & 13.3 & 0.14 & $-0.5(6.3)^{* *}$ & 575 & 167 \\
$1960-69$ & 13.8 & 0.15 & $-0.5(3.7)^{* *}$ & 352 & 123 \\
$>1970$ & 15.5 & 0.16 & $0.2(0.7)$ & 133 & 47 \\
\hline Average & 13.6 & 0.16 & $-0.6(9.0)^{* *}$ & 1277 & 411 \\
\hline Women & & & & & 78 \\
$<1950$ & 11.1 & 0.12 & $-1.4(2.9)^{* *}$ & 18 & 7 \\
$1950-59$ & 12.1 & 0.13 & $-0.7(3.1)^{* *}$ & 131 & 41 \\
$1960-69$ & 11.9 & 0.15 & $0.2(0.8)$ & 85 & 31 \\
$>1970$ & 12.8 & 0.14 & $0.6(0.7)$ & 35 & 7 \\
\hline Average & 12.1 & 0.14 & $-0.4(2.6)^{* *}$ & 269 & 96 \\
\hline
\end{tabular}

b. Individual runner $14-21.1 \mathrm{~km} ; 1988-2008$

\begin{tabular}{lccccc}
\hline Period & $\begin{array}{c}\text { Average speed } \\
(\mathrm{km} / \mathrm{h})\end{array}$ & C.V. & $\begin{array}{c}\text { Change } \\
(\% / \text { year })\end{array}$ & $\begin{array}{c}\text { Number of } \\
\text { observations }\end{array}$ & $\begin{array}{c}\text { Number of } \\
\text { individuals }\end{array}$ \\
\hline $1988-98$ & 12.1 & 0.07 & $-1.7(11.6)^{* *}$ & 167 & 1 \\
$1999-08$ & 10.7 & 0.04 & $-0.9(5.6)^{* *}$ & 187 & 1 \\
\hline Average & 11.3 & 0.08 & $-1.3(19.2)^{* *}$ & 354 & 1 \\
\hline
\end{tabular}

Note: C.V. $=$ coefficient of variation (average/standard deviation); absolute $t$-statistics in parentheses; $* *(*)=$ significant at $5 \%(10 \%)$ level.

Tab. 3: Probability to continue running the $10 \mathrm{~km}$ run; parameters logit model

\begin{tabular}{lccc}
\hline From 2 to 3 & $\Delta \log s_{i t}^{+}$ & $\Delta \log s_{i t}^{-}$ & $\mathrm{N}$ \\
\hline Men & $-0.01(0.4)$ & $0.04(1.5)$ & 392 \\
Women & $-0.18(2.2)^{* *}$ & $0.16(1.4)$ & 86 \\
\hline After 3 & & & \\
\hline Men & $0.02(0.6)$ & $0.03(1.2)$ & 408 \\
Women & $0.08(0.8)$ & $0.02(0.4)$ & 66 \\
\hline
\end{tabular}

Note: absolute $t$-statistics in parentheses; $* *(*)=$ significant at $5 \%(10 \%)$ level. 
running when growing older. It could be that runners who experience a drop in their running speed are more likely to drop out. If so, only the runners that keep fit remain in the sample and the drop in speed when growing older is underestimated. Having data which concern annual observations it is difficult to study attrition. Nevertheless, to get some idea about the possibility of endogenous attrition I estimated the parameters of the following relationship:

$$
c_{i t}=f\left(\Delta \log \left(s_{i t}^{+}\right), \Delta \log \left(s_{i t}^{-}\right)\right)
$$

with $c$ being a dummy variable for continuation and $\Delta \log s^{+}$representing the percentage change in running speed if there was an increase in speed and $\Delta \log s^{-}$representing the percentage change in running speed if there was an decrease in speed. The parameter estimates using a logit specification are given in Table 3. As shown for men the probability to continue from 2 to 3 runs is unaffected by the change in their running speed. Women are less likely to continue running after 2 runs if they face an increase in running speed. It is difficult to come up with an explanation for this phenomenon so it must be coincidence. Continuation after 3 runs is not affected by the change in running speed neither for men nor for women. All in all, there is no evidence of endogenous attrition that would affect the estimated decline of running speed as runners grow older.

\subsubsection{An individual runner}

To further explore the relationship between age and running speed I used individual data over a period of two decades. One of my Tilburg colleagues, Paul van Seters ${ }^{3}$, is a long distance runner who was kind enough to let me use his notes on his running performance. Over a period of 21 years he kept track of his time when running distances from 14 to 21.1 kilometers (half marathon). Table 4 provides information about his data. As shown the average speed was highest for the shortest distance of $14 \mathrm{~km}$, but this run was done in the first decade. Note however that the average speed is almost identical to the average speed of the 1940s birth cohort for the Wolfskamerloop. There is also information about 13 half marathons run in the first decade which were run with an average speed of almost $12 \mathrm{~km} / \mathrm{h}$.

The upper part of Figure 2 shows the 354 data points transferred into speed $(\mathrm{km} / \mathrm{h})$. Clearly there is a decline in running speed but this decline seems stronger in the first

\footnotetext{
${ }^{3}$ http://www.tilburguniversity.nl/globus/people/directors/seters.html.
} 
Fig. 2: Running; individual data 1988-2008

a. All data

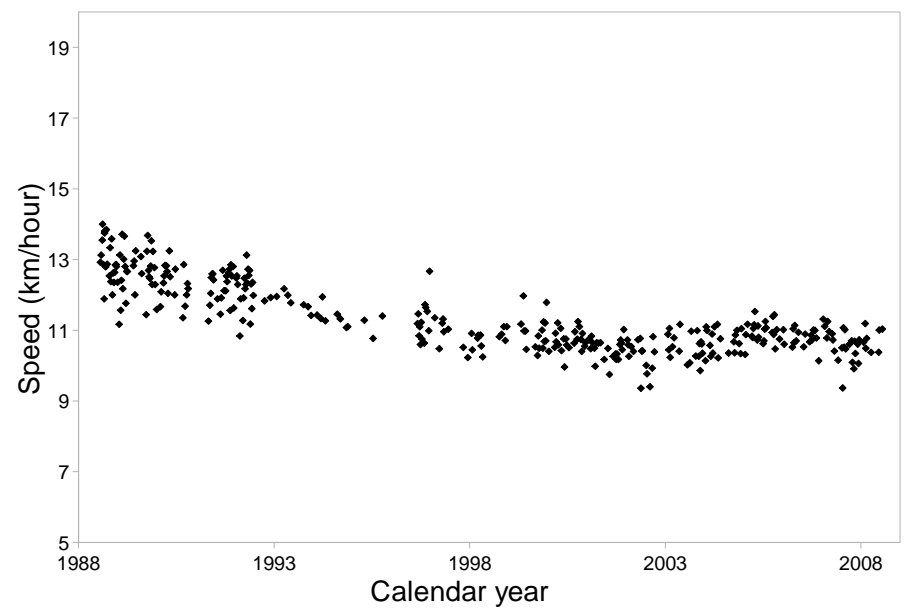

b. Average speed by age

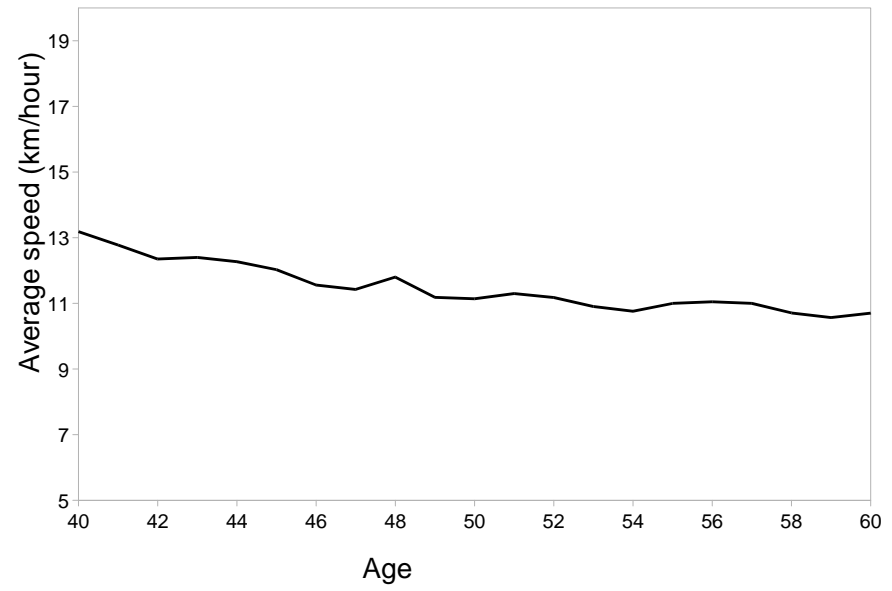


Tab. 4: Data on the individual runner

\begin{tabular}{lccc}
\hline $\begin{array}{l}\text { Distance } \\
(\mathrm{km})\end{array}$ & $\begin{array}{r}\text { Number } \\
\text { of times }\end{array}$ & Years & $\begin{array}{c}\text { Average speed } \\
(\mathrm{km} / \mathrm{h})\end{array}$ \\
\hline 14 & 72 & $1988-95$ & 12.5 \\
$18-19$ & 47 & $2003-08$ & 10.7 \\
19 & 39 & $2005-08$ & 10.4 \\
$19-20$ & 74 & $1996-08$ & 10.5 \\
21 & 109 & $1988-03$ & 11.4 \\
21.1 & 13 & $1989-99$ & 11.8 \\
\hline Total & 354 & $1988-08$ & 11.3 \\
\hline
\end{tabular}

decade than in the second decade. The lower part of Figure 2 which presents annual average confirms this picture. To get some idea about the relationship between speed and age I performed regressions in which calendar month $(2, . ., 12)$, distance dummies $(5)$ and calendar year were explanatory variables.

$$
\log \left(s_{j m t}\right)=\alpha_{j}+\alpha_{m}+\beta a_{j m t}+\epsilon_{j m t}
$$

where the $\alpha_{j}$ are fixed effects for runs of type $j$ (6 distances ranging from 14 to $21.1 \mathrm{~km}$ ), and the $\alpha_{m}$ are fixed effects for calendar month. The parameter estimates are shown in Table 2. Surprisingly but confirming the graphical "eyeball test" the drop in the first 10 years is bigger ( $1.7 \%$ per year) than in the second period $(0.9 \%$ per year). The average annual decline in running speed is remarkably similar to the decline of the 1940s birth cohort for the Wolfskamerloop.

\subsection{Mind: publishing in economics journals}

As indicated before, productivity may change over the life cycle also because cognitive abilities change with age. To get some idea about this relationship I study how publishing in economics journals is related to age. Oster and Hamermesh (1998) find that the productivity of economists as measured by publications in leading journals declines with age. They note that it is difficult to distinguish between two alternative explanations for this phenomenon, natural declines in capacity or reduced incentives to produce.

Economists are fond of measuring productivity including their own productivity. Measuring productivity in terms of publishing performance of economists is not just fun, but is important for several reasons. Evaluation of performance of individuals and departments is an important tool to distribute money. For example, at the Faculty of Economics and 
Business Administration of Tilburg University research funds are allocated to the departments on the basis of research output. Also tenure and promotion decisions are heavily based on the number and quality of publications.

Economists can publish their work in many ways: in books, journal articles, working papers et cetera. However, when it comes to measurement of productivity it is mainly published journal articles that count. Also here, many arbitrary decisions have to be made in order to establish productivity (see Van Ours and Vermeulen, 2007). How should one account for the length of an article? Is an article that is twice as long also twice as important? How should one account for co-authorship? Should the size of the pages be standardized? The quality weight of an article is perhaps the most controversial issue (Neary et al., 2003). Usually the quality weight of an article is determined by the journal in which it appears. Then, the quality of a journal is often determined by its impact factor which is based on the number of times the journal is cited over a particular period of time. This too is not uncontroversial. Oswald (2007) shows that the best articles published in medium-quality journals are cited more often than the worst articles that are published in top journals.

To some extent publications in economic journals does not represent a good measure of individual productivity because as academics grow older the nature of their work may change. Older academics participate in committees, supervise Ph.D. students and perform other administrative duties. Also, the incentives to publish are bigger for academics on tenure track than for academics on tenured positions. However, to the extent that supervisors are able to attract bright Ph.D. students they may also benefit in the form of joint publications. ${ }^{4}$

In my empirical use publication records of the members of the Department of Economics of Tilburg University with at least 2 international publications. To quantify the publications I use the Tinbergen Institute (TI) classification of journals, which distinguishes between $A A, A$ and $B$ journals. ${ }^{5}$ I classify all publications in scientific journals

\footnotetext{
${ }^{4}$ Van Ours and Ridder (2003) find that supervisors who publish frequently are able to attract Ph.D. students who are less likely to dropout and complete their dissertation earlier.

${ }^{5}$ The AA journals are American Economic Review, Econometrica, Journal of Political Economy, Quarterly Journal of Economics and Review of Economic Studies. Van Ours and Vermeulen (2007) provide the full list; the TI list is based on Kalaitzidakis et al. (2003) transferring the cardinal ranking of economics journals to an ordinal ranking using three categories. Of course the TI list is also arbitrary but at least the top 5 of $A A$ journals seems to get wide support.
} 
Tab. 5: Data on publishing in economics journals

\begin{tabular}{lcccccc}
\hline & & & \multicolumn{3}{c}{ Average } \\
Birth year & AA & A & B & C & score & Economists \\
\hline$<1955$ & $4(1)$ & $37(5)$ & $130(9)$ & $160(10)$ & 57 & 10 \\
$1955-64$ & $9(3)$ & $54(6)$ & $118(6)$ & $51(6)$ & 96 & 6 \\
$\geq 1965$ & $5(1)$ & $37(8)$ & $76(11)$ & $67(13)$ & 31 & 13 \\
\hline Total & $18(5)$ & $128(19)$ & $324(26)$ & $278(29)$ & 55 & 29 \\
\hline Average age & 40.2 & 40.8 & 40.6 & 42.6 & - & - \\
Minimum age & 30 & 28 & 25 & 26 & - & - \\
Maximum age & 52 & 57 & 60 & 62 & - & - \\
\hline
\end{tabular}

Note: in parentheses the number of economists contributing to the publications.

which are not $A A, A$, or $B$ as $C$ journals. As shown in Table 5 the data refer to 29 economists who published $18 A A, 128 A, 324 B$ and $278 C$ articles. To quantify the productivity I add-up all publications using as weights, $C=1, B=2, A=4, A A=8{ }^{6}$ Then, the average score per economist is 55 . Table 5 also distinguishes publications by birth cohort. The average score per economist born before 1955 is 57; the average score for economists born between 1955 and 1965 is 96 which is remarkable since the latter group has had less calendar time to generate publications. Finally Table 5 shows that there is no obvious minimum or maximum age for publications; even $A A$ papers were published by economists of very different ages.

The top part of Figure 3 gives a graphical representation of the available information. As shown there is a lot of variation in publications. There are many years for which individual economists have no publication at all. But, there are also several observations of individuals who had a publication value of more than 20 within one year. The bottom part of Figure 3 shows average publication scores by year. Apart from publications being a bit lower below age 35 there is no obvious age pattern in these annual publication scores.

To quantify the relationship between publishing and age I estimated the following equation:

$$
p_{i t}=\alpha_{i}+\beta a_{i t}+\epsilon_{i t}
$$

where $p$ is the weighted number of publications, $a$ is the age at the time of the publication, $i$ represents individual, $t$ represents time, $\alpha_{i}$ are individual fixed effects, $\beta$ is the parameter

\footnotetext{
${ }^{6}$ I investigated different weight structures (1-2-3-4; 0-2-4-8) and looked how sensitive the empirical results are to accounting for co-authors. By and large the results are very much the same.
} 
Fig. 3: Publishing in economics journals; 1977-2008

a. All data

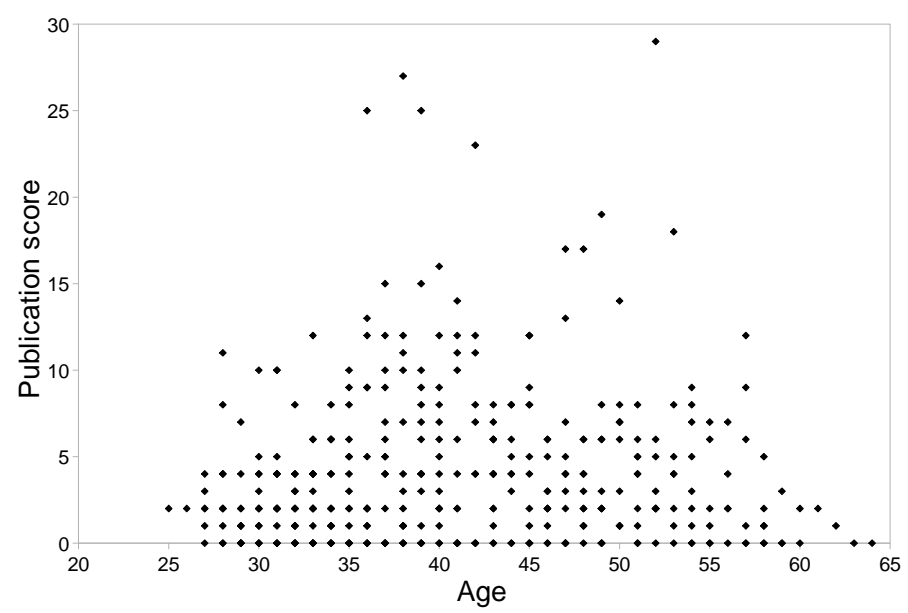

b. Average publication score by age

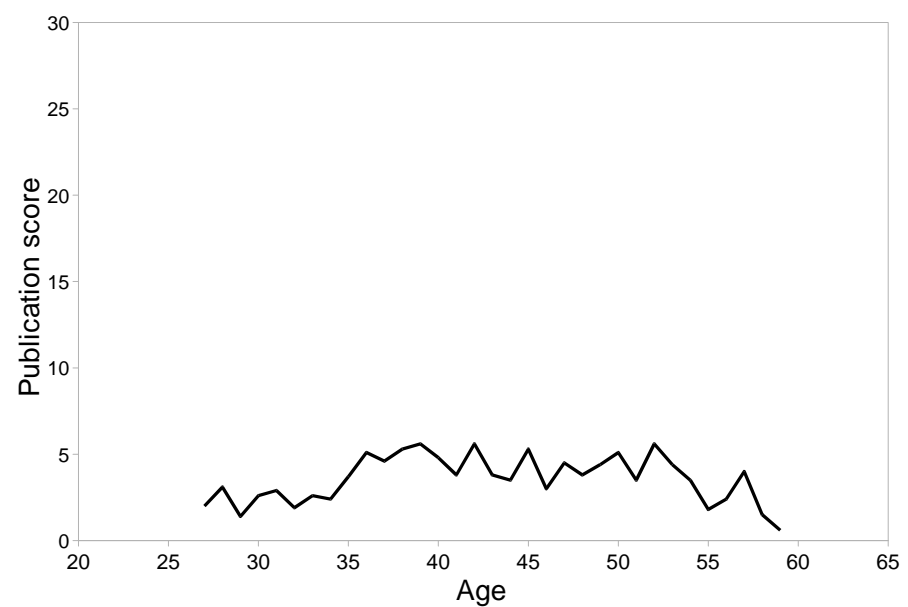


of interest, and $\epsilon$ is the error term. This equation relates age at the time of the publication to the publication. Of course taking into account the time period from writing, via submitting, through acceptation to publication it is very hard to pinpoint the actual publication to the productive age since this time period may cover many, many years. Also, getting a paper published in December of year $t$ rather than in January of year $t+1$ means that productivity in year $t(t+1)$ might be overestimated (underestimated) ${ }^{7}$

Table 6 shows the parameter estimates. On average, productivity increases with 0.15 per year. However, there are differences between age groups and birth cohorts. Below age 40 the average production score increases with 0.35 per year. Above age 40 there is no relationship between publishing and age. By splitting up the sample according to age some individuals are spread out over different groups. Therefore the second part of Table 6 shows parameter estimates when the sample is split-up according to birth cohort. There are differences between birth cohorts but for every cohort there is a positive age effect. ${ }^{8}$ The age effect is largest for the youngest cohort, but the oldest cohort has a larger age effect than the cohort born between 1955 and 1965. The lowest part of Table 6 shows parameter estimates distinguishing between birth cohorts and age. Once above age 40 the oldest cohort still had a positive age effect while the cohort born between 1955 and 1965 had no positive age effect. Once above age 50 also the oldest cohort has no positive age effect, but it doesn't have a negative age effect either.

All in all, it is clear that the cohort born between 1955 and 1965 is more productive than the older cohort. Apparently, the economists in this cohort are more talented in terms of publication skills, which may be attributed to the hiring policy of the department. Nevertheless once time-invariant individual characteristics are taken into account productivity increases with age up to age 50 and stays constant after that.

\section{Firm level productivity}

\subsection{Recent empirical studies}

Recently a number of longitudinal studies used matched worker-firm data to investigate the relationship between age, wage and productivity. Aubert (2003) shows that the age-

\footnotetext{
${ }^{7}$ This is one of the reasons why production is sometimes measured as moving averages over several years.

${ }^{8}$ Note that this age effect is indistinguishable from a positive calendar time effect which could be attributed to the increasing pressure in academia to publish (or perish).
} 
Tab. 6: Parameter estimates individual productivity - publishing in economics journals; $1977-2008$

\begin{tabular}{lcccc}
\hline Age & $\begin{array}{c}\text { Average } \\
\text { score }\end{array}$ & $\begin{array}{c}\text { Change } \\
(\% / \text { year })\end{array}$ & $\begin{array}{c}\text { Number of } \\
\text { observations }\end{array}$ & $\begin{array}{c}\text { Number of } \\
\text { individuals }\end{array}$ \\
\hline$<40$ & 3.43 & $0.35(4.5)^{* *}$ & 206 & 25 \\
$40-50$ & 4.28 & $0.04(0.4)$ & 131 & 18 \\
$\geq 50$ & 2.48 & $-0.04(0.3)$ & 93 & 12 \\
\hline Birth year & & & & 10 \\
\hline$<1955$ & 3.03 & $0.13(4.4)^{* *}$ & 198 & 6 \\
$1955-65$ & 4.46 & $0.06(2.9)^{* *}$ & 129 & 13 \\
$\geq 1965$ & 2.97 & $0.23(2.4)^{* *}$ & 103 & 29 \\
\hline Average & 3.41 & $0.15(5.6)^{* *}$ & 430 & 10 \\
\hline & & & 6 \\
Age $\geq 40$ & & & 156 & \\
\hline$<1955$ & 3.40 & $0.14(2.7)^{* *}$ \\
$1955-65$ & 4.84 & $-0.03(0.2)$ & 58 & 10 \\
\hline Age $\geq 50$ & & & \\
\hline$<1955$ & 3.24 & $-0.02(0.2)$ & \\
\hline
\end{tabular}

Note: absolute $t$-statistics in parentheses; $* *(*)=$ significant at $5 \%(10 \%)$ level.

productivity profile in France is increasing and concave, with high skilled workers having the steepest age-productivity profile. Furthermore, there seems to be a decrease of the productivity of unskilled workers after 55. Ilmakunnas and Maliranta (2005) estimate production functions and wage equations on Finnish data. The pay-productivity gap for older workers is among the most robust results. On the basis of an analysis of Canadian data, Dostie (2006) concludes that both wage and productivity profiles are concave, but productivity is diminishing faster than wages for workers aged 55 and over. Aubert and Crépon (2007) find that productivity, defined as the average contribution of particular age groups to the productivity of firms, increases with age until age 40 to 45 and then remains stable after this age. The results are stable across industries. They also show that the age-productivity profile is similar to the age-labor cost profile which is contradicting the overpayment of older workers. The evidence for what happens after 55 remains inconclusive due to data and precision issues. Ilmakunnas and Maliranta (2007) examine the connection of aging work force to firm performance by using information on the hiring and separation of Finnish employees. They show that separations of older workers are profitable to firms, especially in the manufacturing ICT-industries, because there are indeed 
differences between the age groups in their relative productivity and wage levels. BörschSupan et al. (2007) analyzing data from an assembly plant of a German car manufacturer find that age has a negative effect on productivity, but tenure has a positive effect of the same magnitude. Malmberg et al. (2008) use Swedish data to study how the value added per worker is affected by average age, education and tenure of the worker. They find that once plant-level effects are accounted for, high shares of older workers are associated with higher firm-level productivity. All in all, the empirical evidence concerning an age related productivity decline and an age related pay-productivity gap is conflicting.

\subsection{Empirical analysis}

To study the relationship between age, wage and productivity at the firm level I use matched worker-firm data collected by Statistics Netherlands. ${ }^{9}$ The data concern a balanced panel of Dutch manufacturing firms providing information about value-added, employment, total wages, the composition of the workforce and depreciation of fixed assets. ${ }^{10}$ The dataset covers the period 2000-2005 and comprises almost 3,000 firms. Employment is measured by the number of social insurance days, i.e. the number of days for which social insurance is paid by the firm. The composition of the workforce in each firm is computed by using personal information about age and gender. In each firm eight age groups are distinguished: $<25,25-29,30-34,35-39,40-44,45-49,50-56$ and $\leq 57$. Table 7 presents some descriptive statistics.

To establish the relationship between age and productivity the following equation is estimated (following Aubert and Crépon, 2007):

$$
\log \left(Q_{i t}\right)=\alpha_{i}^{q}+\alpha_{t}^{q}+\sum_{k} \gamma_{k} l_{k i t}+\beta_{1} \log \left(L_{i t}\right)+\beta_{2} \log \left(K_{i t}\right)+\beta_{3} s_{f}+\varepsilon_{i t}^{q}
$$

where $Q$ is value added, $L$ is employment, $K$ is capital, $l_{k}$ is the fraction of age category $k$ in total employment, $s_{f}$ is the share of female workers in the firm, the $\alpha$ 's are fixed effects for calendar year and firm; the $\gamma_{k}$ are the main parameters of interest. Similarly a labor costs equation is estimated:

$$
\log \left(w_{i t}\right)=\alpha_{i}^{w}+\alpha_{t}^{w}+\sum_{k} \xi_{k} l_{k i t}+\beta_{4} \log \left(L_{i t}\right)+\beta_{5} s_{f}+\varepsilon_{i t}^{w}
$$

\footnotetext{
${ }^{9}$ See for details: Van Ours and Stoeldraijer (2009).

${ }^{10}$ Lacking information about the value of the capital stock, the depreciation on fixed assets is used as a proxy for the capital stock.
} 
Tab. 7: Descriptive statistics of the matched worker-firm dataset

\begin{tabular}{lrrrr}
\hline & Mean & Std. Dev. & Min & Max \\
\hline & & & & \\
Log value added (Euro 1000) & 8.22 & 1.20 & 2.56 & 14.81 \\
Log total cost of labor (Euro 1000) & 7.87 & 1.11 & 3.89 & 14.32 \\
Log depreciation (Euro 1000) & 5.83 & 1.51 & 0 & 13.14 \\
Employment (Workers) & 166 & 758 & 5 & 41648 \\
Employment (Days) & 135 & 633 & 2.6 & 34663 \\
Proportions age categories: & Workers & Days & & \\
$<25$ & 0.14 & 0.10 & & \\
$25-29$ & 0.10 & 0.10 & & \\
$30-34$ & 0.15 & 0.15 & & \\
$35-39$ & 0.15 & 0.16 & & \\
$40-44$ & 0.14 & 0.15 & & \\
$45-49$ & 0.11 & 0.12 & & \\
$50-56$ & 0.13 & 0.14 & & \\
$\geq 57$ & 0.07 & 0.07 & & \\
Proportion female: & 0.24 & 0.15 & & \\
\hline
\end{tabular}

Note: The panel concerns information on 2905 firms providing 17,430 observations.

where $w$ represents the average labor costs per worker. Equality between relative labor cost and relative productivity can be tested through a test of the equality of the estimated coefficients $\gamma_{k}$ and $\xi_{k}$.

Different methods are used to estimate the equations. First I present pooled crosssection estimates. The interpretation of these estimation results is that an age group is more productive than another group if a firm with a higher share of this age group on average produces more than a comparable firm with a lower share for this age group. The results from the fixed effects estimation can be interpreted as follows: a group is estimated to be more productive than another group if, within a firm, production increases when the share of labor of the group increases. With firm fixed effects the relationship is identified as an average over within firm variation. Although the introduction of firm fixed effects removes potential spurious correlation between age composition and productivity it doesn't solve all problems. Changes in age composition may not be exogenous to changes in productivity. It could be that a negative productivity shock induces firms to fire young workers, causing the average age of the workforce to increase. Then, a negative productivity shock correlates with an increase in average age of the workforce while in fact there is an exogenous explanation for this correlation. To address this potential bias, 
the third estimation uses an instrumental variables approach. Then both equations are estimated in terms of first differences instrumenting the changes in age shares. ${ }^{11}$

Tab. 8: Estimation of production and labor cost functions - I

\begin{tabular}{|c|c|c|c|c|c|c|}
\hline & \multicolumn{3}{|c|}{ Production function } & \multicolumn{3}{|c|}{ Labor cost function } \\
\hline & 1 & 2 & 3 & 1 & 2 & 3 \\
\hline \multicolumn{7}{|l|}{ Age groups } \\
\hline$<25$ & $-0.71(10.8)^{* *}$ & $0.17(2.1)^{* *}$ & $-0.20(0.5)$ & $-1.16(24.3)^{* *}$ & $-0.01(0.2)$ & $-0.51(1.8)^{*}$ \\
\hline $25-29$ & $0.15(1.9)^{*}$ & $0.08(1.0)$ & $-0.45(1.3)$ & $-0.19(3.3)^{* *}$ & $0.12(2.0)^{* *}$ & $-0.53(2.2)^{* *}$ \\
\hline $30-34$ & $0.13(1.8)^{*}$ & $0.09(1.3)$ & $-0.16(0.6)$ & $-0.06(1.1)$ & $0.10(2.0)^{*}$ & $-0.11(0.6)$ \\
\hline $35-39$ & - & - & - & - & - & - \\
\hline $40-44$ & $-0.05(0.7)$ & $0.00(0.1)$ & $0.26(1.1)$ & $-0.07(1.3)$ & $0.05(0.9)$ & $0.10(0.6)$ \\
\hline $45-49$ & $-0.01(0.1)$ & $-0.03(0.4)$ & $0.22(0.6)$ & $-0.06(1.0)$ & $-0.04(0.7)$ & $0.15(0.6)$ \\
\hline $50-56$ & $0.10(1.5)$ & $-0.24(3.0)^{* *}$ & $0.17(0.4)$ & $0.16(3.2)^{* *}$ & $-0.13(2.2)^{* *}$ & $0.12(0.4)$ \\
\hline$\geq 57$ & $0.08(1.0)$ & $-0.24(2.5)^{* *}$ & $-0.29(0.5)$ & $0.04(0.7)$ & $-0.20(2.9)^{* *}$ & $-0.30(0.8)$ \\
\hline Employment & $0.79(154.9)^{* *}$ & $0.38(25.5)^{* *}$ & $0.24(9.1)^{* *}$ & $0.05(20.1)^{* *}$ & $-0.47(42.9) * *$ & $-0.62(33.6)^{* *}$ \\
\hline Capital & $0.25(75.7)^{* *}$ & $0.23(42.8)^{* *}$ & $0.23(35.3)^{* *}$ & - & - & - \\
\hline Females & $-0.39(17.9)^{* *}$ & $0.10(1.6)$ & $0.10(1.5)$ & $-0.49(30.3)^{* *}$ & $-0.12(2.6)^{* *}$ & $0.02(0.4)$ \\
\hline Sargan statistic & - & - & 6.8 & - & - & $21.3^{* *}$ \\
\hline Observations & 17430 & 17430 & 11620 & 17430 & 17430 & 11620 \\
\hline
\end{tabular}

Note: Estimates include year dummies. $1=$ pooled cross-section, $2=$ including firm fixed effects, $3=$ first differences instrumenting the change in age shares with 2 and 3 period lagged levels of age shares; industry sector firms with at least 5 employees; the balanced panel concerns information about 2905 firms; Sargan statistic $=$ overidentification test of all instruments; absolute $t$-statistics in parentheses; ${ }^{* *}(*)=$ significant at $5 \%(10 \%)$ level.

Table 8 presents the parameter estimates in detail while Figure 4 gives a graphical representation of the relevant parameter estimates. The first three columns of table 8 present the estimates of the production function. The pooled cross-section parameter estimates indicate that productivity is low for firms with a high share of young workers. The productivity is not much affected by the shares of the other age groups. Employment and capital have a positive effect on production. A higher share of female workers has a negative effect on the productivity of the firm which is most likely due to the high share of part-time

\footnotetext{
${ }^{11}$ The $\Delta l_{k i t}$ variables are instrumented with $l_{k i, t-2}, l_{k i, t-3}$ as well as 2-period and 3-period lagged values of the other determinants. Alternative specifications were tried including instruments using fewer lags or specifying equations in levels using lagged first differences as instruments. Although the outcomes of the various specifications differed the general pattern of age-productivity and age-wage profiles is very much the same.
} 
Fig. 4: Age-productivity and labor costs profiles - Dutch manufacturing

a. Pooled cross-section

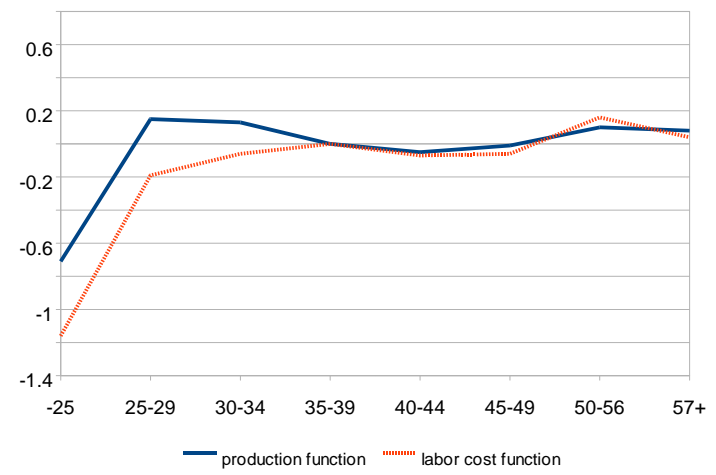

b. Firm fixed effects

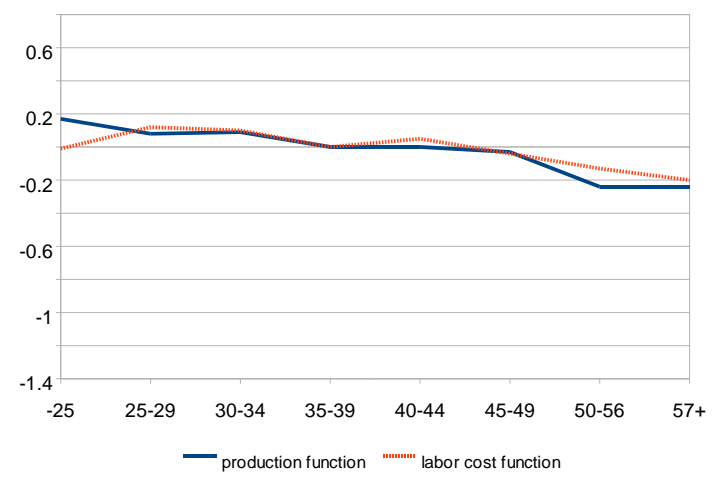

c. First differences - accounting for endogeneity

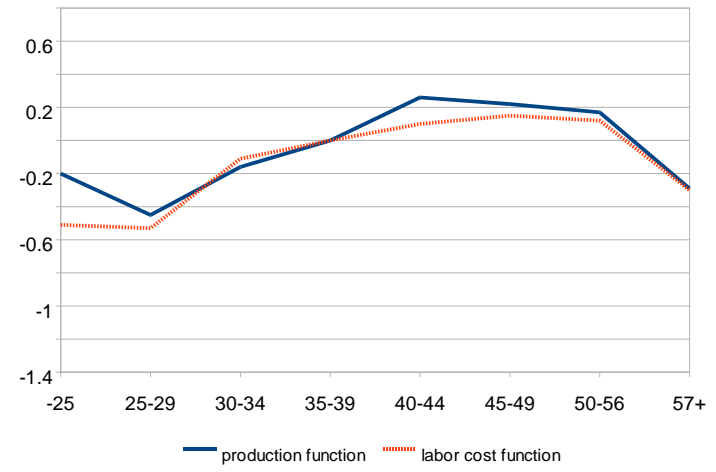


working women. The fixed effects estimates show a declining productivity with age. Employment and capital have positive effects on production, while the gender composition of a firms' workforce has no effect on production. The instrumental variable estimation results presented in the third column indicate an inverse U-shape age-productivity profile. However, none of the estimates age-group parameter is different from zero at conventional levels of significance. ${ }^{12}$

Tab. 9: Estimation of production and labor cost functions - II

\begin{tabular}{lcccc}
\hline & \multicolumn{2}{c}{ Production function } & \multicolumn{2}{c}{ Labor cost function } \\
& 1 & 2 & 1 & 2 \\
\hline Age/10 & $0.06(0.1)$ & $0.30(1.7)^{*}$ & $0.59(1.0)$ & $0.38(3.0)^{* *}$ \\
Age-squared/10 & $0.39(0.3)$ & - & $-0.35(0.4)$ & - \\
Employment & $0.27(8.4)^{* *}$ & $0.27(8.5)^{* *}$ & $-0.60(26.7)^{* *}$ & $-0.59(26.9)^{* *}$ \\
Capital & $0.23(35.1)^{* *}$ & $0.23(35.4)^{* *}$ & - & - \\
Female & $0.17(2.1)^{* *}$ & $0.15(2.1)^{* *}$ & $0.07(1.3)$ & $0.09(1.7)^{*}$ \\
\hline Sargan statistic & 3.4 & 3.4 & $13.1^{* *}$ & $12.8^{* *}$ \\
\hline
\end{tabular}

Note: Estimates include year dummies; all estimates concern first differences instrumenting the change in age and age-squared with 2 and 3 period lagged levels of age and age-squared; industry sector firms with at least 5 employees; the estimates are based on 11,620 observations; Sargan statistic $=$ overidentification test of all instruments; absolute $t$-statistics in parentheses; $* *(*)=$ significant at $5 \%(10 \%)$ level.

The last three columns of Table 8 present the estimates of the labor cost equation. To compare this profile to the age-productivity profile, the labor cost equation is estimated under the same specifications as the production function (except for capital, which is not included). The dependent variable is the total labor cost divided by the total number of employees at the firm using the number of social insurance days. Surprisingly, the agegroup parameter estimates for the wage costs function are very similar to the parameter estimates for the production function. In other words, the age-productivity and the agelabor costs profiles follow each other closely. The instrumental variable method produces few significant parameter estimates; the share of workers below age 30 being the exception. ${ }^{13}$ The estimated age-productivity and age-labor costs profiles plotted in Figure 4

\footnotetext{
${ }^{12}$ The first-stage regressions of the endogenous variables on the instruments and the other explanatory variables show a strong correlation between endogenous variables and instruments, with $F$-statistics larger than 40. The Sargan statistic represents a test on overidentifying restrictions. As this statistic is insignificantly different from zero, independence of instruments and error terms in the main equation cannot be rejected.

${ }^{13}$ For the instrumental variable estimates the first stage showed no evidence of weak instruments. How-
} 
show that indeed productivity and labor costs move closely together.

Finally, to investigate the age-wage-productivity relationship in more detail Table 9 presents parameter estimates in which the average age of the firms' workforce is used as explanatory variable. To account for non-linearities in the relationship age-squared is also used as explanatory variable. As shown, there is no evidence of non-linearities in age, neither for productivity nor for wage costs. ${ }^{14}$ However, there is a positive effect of age on productivity and labor costs, with the influence of age on labor costs being somewhat larger than the effect of age on productivity. Nevertheless, the difference between the two parameter estimates is not significant.

\section{Conclusions}

To shed some light on the relationship between age and productivity I analyzed individual data on running and publishing and firm data. To the extent that running performance represents physical productivity I find evidence of a productivity decline after age 40 . To the extent that publishing in economics journals represents mental productivity I do not find evidence of a productivity decline, even after age 40 . When measured at the firm level I find little evidence of an increasing pay-productivity gap at higher ages. These empirical findings are limited to the extent that they are based on Dutch data focussing on single dimensions of productivity. Running is used as an example of physical fitness, publishing as an example of mental ability. Both samples I used in the analysis concern small groups which are most likely not representative for the Dutch labor force. Nevertheless, the results are in line with previous studies. Using firm level data on age and productivity is limited to the extent that the complexity of the age-productivity relationship is not well represented by using average age or age categories within a firm. How age will affect firm-level productivity will also depend on the nature of the production process and how age groups are combined in the organization of the production process.

Studying the relationship between age and economic productivity is not easy. There is a fundamental identification problem because in most cases productivity is an aggregate measure at the level of firms. Future research should be directed to studying different ever, the Sargan test for overidentifying restrictions is rejected.

${ }^{14}$ As before the first stage regressions showed no evidence of weak instruments, the Sargan statistic is insignificant for the production function estimates, while the Sargan test for overidentifying restrictions is rejected for the labor costs estimates. 
industries with different skill compositions of the workforce, investigating the productivity effects of age-related accessions and separations of workers and studying age-wage profiles within firms.

Despite the limitations of the empirical analysis some conclusions can be drawn. My main conclusion is that the potential negative effects of aging on productivity should not be underestimated; they should not be exaggerated either. There is no need to worry too much about age-related productivity declines or an age related pay-productivity gap. Nevertheless, the labor market position of older workers will remain an area of policy concern. After all, once older workers becomes unemployed they are not very likely to return to a job.

\section{References}

[1] Aubert, P. (2003) Productivity, wage and demand for elder workers; an examination on French matched employer-employee data, Working Paper INSEE, Paris.

[2] Aubert, P. and B. Crépon (2007) Are older workers less productive? Firm-level evidence on age-productivity and age-wage profiles, mimeo (French version published in: Economie et Statistique, 2003,368,95-119).

[3] Börsch-Supan, A., I. Düzgün, and M. Weiss (2007) Age and productivity in work teams: evidence from the assembly line, MEA Discussion Paper, University of Mannheim.

[4] Dostie, B. (2006) Wages, productivity and aging, Working Paper Institute of Applied Economics, Montreal.

[5] Fair, R.C. (1994) How fast do old men slow down? Review of Economics and Statistics, $76,103-118$.

[6] Garibaldi, P., J. Oliveira Martins and J.C. van Ours (2010) Health, Longevity and Productivity, Oxford University Press, forthcoming.

[7] Ilmakunnas, P. and Maliranta, M. (2005) Technology, worker characteristics, and wage-productivity gaps, Oxford Bulletin of Economics and Statistics, 67, 623-645. 
[8] Ilmakunnas, P. and M. Maliranta (2007) Aging, labor turnover and firm performance, Discussion Paper Research Institute of the Finnish Economy, Helsinki.

[9] Johnson, P. (1993) Aging and European economic demography, in: Johnson, P. and K.F. Zimmermann (eds.) Labor markets in an aging Europe, Cambridge University Press, Cambridge.

[10] Kalaitzidakis, P., T. Mamuneas and T. Stengos (2003) Ranking of academic journals and institutions in economics, Journal of the European Economic Association, 1, $1346-1366$.

[11] Lazear, E. (1979) Why is there mandatory retirement? Journal of Political Economy, $87,1261-1284$.

[12] Loewenstein, G. and N. Sicherman (1991) Do workers prefer increasing profiles? Journal of Labor Economics, 9, 67-84.

[13] Malmberg, B., T. Lindh and M. Halvarsson (2008) Productivity consequences of workforce aging: stagnation or Horndal effect? Population and Development Review, $34,238-256$.

[14] Neary, J.P., J.A. Mirrlees and J. Tirole (2003) Evaluating economics research in Europe: an introduction, Journal of the European Economic Association, 1, 12391249 .

[15] OECD (2006) Live longer, work longer, Paris.

[16] Oster, S.M. and D.S. Hamermesh (1998) Aging and productivity among economists, Review of Economics and Statistics, 80, 1, 154-156.

[17] Oswald, A.J. (2007) An examination of the reliability of prestigious scholarly journals: evidence and implications for decision-makers, Economica, 74, 21-31.

[18] Skirbekk, V. (2003) Age and individual productivity: a literature survey, Working Paper Max-Planck Institute, Rostock.

[19] Sterken, E. (2003) From the cradle to the grave: how fast can we run? Journal of Sports Science, 21, 479-491. 
[20] Van Ours, J.C. and G. Ridder (2003) Fast track or failure: a study of the graduation and dropout rates of Ph.D. students in economics, Economics of Education Review, $22,157-166$.

[21] Van Ours, J.C. and F. Vermeulen (2007) Ranking Dutch economists, De Economist, $155,469-487$.

[22] Van Ours, J.C. and L. Stoeldraijer (2009) Age, wage and productivity in Dutch firms, mimeo, Tilburg University.

[23] Van Vuuren, D. and P. de Hek (2009) Firms, workers, and life-cycle wage profiles, in Euwals, R., R. de Mooij and D. van Vuuren (2009) Rethinking Retirement, CPB Netherlands Bureau for Economic Policy Analysis, The Hague.

[24] Weiss, Y. (1985) The effect of labor unions on investment in training: a dynamic model, Journal of Political Economy, 93, 994-1007. 